\title{
KEPATUHAN WAJIB PAJAK (WP) DALAM MELAPORKAN SPT TAHUNAN DI MASA PANDEMI COVID-19 PADA KPP PRATAMA MATARAM BARAT
}

\author{
Muaidy Yasin \\ Fakultas Ekonomi dan Bisnis Universitas Mataram \\ muaidyyasin@unram.ac.id \\ Mila Safitri \\ Fakultas Ekonomi dan Bisnis Universitas Mataram \\ milasafitri011@gmail.com
}

\begin{abstract}
ABSTRAK
Indonesia merupakan negara berkembang yang memiliki sumber pendapatan Terbesar dari pajak, Dimana $82,85 \%$ pendapatan Negara Bersumber dari penerimaan pajak, Kemudian sisanya dari Penerimaan Bukan Pajak (PNBP) sebasar 17,1\% dan Hibah sebesar 0,05\%.(Sumber Https://www.kemengku.go.id)

Pajak memiliki peranan besar dalam pembiayaan pembangunan nasional dan pelayanan kesejahteraan masyarakat, Oleh karna itu Kepatuhan Wajib pajak dalam membayarkan dan Melaporkan pajaknya sangat besar pengaruhnya untuk negara ini.

Tujuan dari penelitian ini adalah untuk mengetahui Tingkat kepatuhanWajib Pajak (Wajib Pajak Orang Pribadi dan Wajib Pajak Badan) dalam pelaporan SPT Tahunan Sebelum dan Sesudah Pandemi Covid-19 di Kantor Pelayanan Pajak Pratama Mataram Barat. Penelitian ni dilaksanakan di KPP Pratama Mataram Barat yang terletak di Jln. Langko No.74 Pejeruk, Kec.Ampen, Kota Mataram.

Dari Data Yang di Laporkan di KPP Pratama Mataram Barat menunjukkan bahwa: (1) Persentasi tingkat kepatuhan Wajib Pajak di KPP Pratama mataram Barat dalam Membayarkan pajakanya di Tahun 2018 adalah sebesar $94,30 \%$ yang tergolong dalam kriteria kepatuhan yang sangat tinggi, kemudian menurun di tahun 2019 menjadi 92,78 \% namun masih termasuk dalam kriteria kepatuhan sangat tinggi, dan selanjutnya di tahun 2020 juga kembali menurun menjadi $81,67 \%$ yang mana kriteria kepatuhannya tergolong Tinggi. (2) Tingkat kepatuhan Wajib Pajak Orang Pribadi dalam pelaporan SPT di KPP Pratama Mataram Barat pada saat Sebelum Pandemi Covid-19 Di Tahun 2018 dan 2019 adalah sebesar 37,34\%, dan 28,02\% ,Kemudian Menurun Setelah Penyebaran Covid-19 Di Tahun 2020 menjadi 24,50\%, yang tergolong dalam kategori rendah menurut norma skala lima. (2) Tingkat kepatuhan Badan dalam pelaporan SPT di KPP Pratama Mataram Barat pada saat Sebelum Pandemi Covid-19 Di Tahun 2018 dan 2019 adalah sebesar 22,49\%, dan 15,43\%, Kemudian Menurun Setelah Pandemi Covid-19 Di Tahun 2020 menjadi $8,01 \%$, yang tergolong dalam kategori rendah menurut norma skala lima.

Dari Uraian di atas dapat Disimpulkan Bahwa Tingkat Kepatuhan Wajib Pajak Orang Pribadi maupun Wajb Pajak Badan Dalam Melaporkan SPT Tahunan di KPP Pratama Mataram Barat sejak tahun 2018 dan 2019 mengalami penurunan dan masih tergolong dalam kategori Rendah Bahkan sebelum Pademi Covid-19, Dan Kemudin Terus Menurun Setelah Pandemi Covid19 di tahun 2020, yang mana Berbanding terbalik dengan persentasi tingkat penerimaan pajaknya yang tergolong tinggi. sehingga dapat disimpulkan bahawa faktor penyebab rendahnya tinggkat kepatuhan Wajib Pajak dalam melaporkan SPT Tahunannya adalah karena kurangnya kesadaran dari WP mengenai pentingnya melaporkan Pajaknya dan kurangnya pengetahuan dalam pelaporan SPT Tahunan secara Online melalui E-Filing.
\end{abstract}

Kata kunci: Pelaporan SPT, Pandemi Covid-19 
Muaidy Yasin, Mila Safitri : Kepatuhan Wajib Pajak.... 


\section{PENDAHULUAN}

Indonesia merupakan negara berkembang yang memiliki sumber pendapatan Terbesar dari penerimaan pajak. Dimana $82,85 \%$ pendapatan Negara Bersumber dari penerimaan pajak, Kemudian sisanya dari Penerimaan Bukan Pajak (PNBP) sebsar 17,1\% dan Hibah sebesar 0,05\%. (Sumber Https://www.kemengku.go.id)

Pajak memiliki peran yang besar dalam pembiayaan pembangunan nasional dan pelayanan kesejahteraan masyarakat. Pembiayaan ini telah diatur oleh negara dalam Anggaran Pendapatan dan Belanja Negara (APBN), Oleh karna itu Kepatuhan Wajib Pajak Dalam Hal Membayarkan dan Melaporkan pajaknya sangat penting bagi Negara.

Sistem pemungutan pajak di Indonesia menggunakan Self Assesment System. Melalui sistem ini, Wajib Pajak diberi wewenang untuk menentukan sendiri besarnya pajak terutang dengan menghitung, menyetor, dan melaporkan sendiri pajak yang terutang dengan menyampaikan SuratPemberitahuan. Sedangkan pihak fiskus dipercaya untuk mengawasi sesuai undang-undang yang berlaku. Tujuan dari sistem ini yaitu untuk mengetahui apakah Wajib Pajak bisa menjaga kepercayaan yang diberikan.

Surat Pemberitahuan (SPT) adalah surat yang digunakan oleh Wajib Pajak untuk melaporkan penghitungan dan/atau pembayaran pajak, ObjekPajak dan/atau bukan Objek Pajak, dan/atau harta dan kewajiban sesuai dengan ketentuan peraturan perundang-undangan perpajakan. Fungsi dari Surat Pemberitahuan adalah untuk mengawasi penerimaan pajak. Oleh karena itu, kepatuhan Wajib Pajak dalam pelaporan SPT harus ditingkatkan agar pengawasan penerimaan pajak menjadi efektif. Kepatuhan Wajib Pajak dalam pelaporan SPT dapat dilihat dari apakah SPT telah dilaporkan oleh Wajib Pajak atau belum, pengisian SPT harus benar, jelas, dan dilengkapi dengan lampiran-lampirannya serta harus dilaporkan sesuai dengan batas waktu yang telah ditentukan. Pelaporan SPT ini menjadi indikator persentase tingkat kepatuhan Wajib Pajak dalam membayar pajak. Semakin tinggi persentase pelaporan SPT maka semakin tinggi pula tingkat kepatuhan Wajib Pajak.

Wajib Pajak yang patuh adalah Wajib Pajak yang taat dan memenuhi serta melaksanakan kewajiban perpajakan sesuai dengan ketentuan peraturan perundangundangan perpajakan. Ada dua macam kepatuhan, yaitu kepatuhan formal dan kepatuhan material. Kepatuhan formal adalah suatu keadaan di mana Wajib Pajak memenuhi kewajiban secara formal sesuai dengan ketentuan perundang-undangan perpajakan. Misalnya Wajib Pajak Orang Pribadi melaporkan SPT sebelum atau pada tanggal 31 Maret, maka Wajib Pajak telah memenuhi ketentuan formal. Kepatuhan material yaitu suatu keadaan di mana Wajib Pajak secara substantif memenuhi semua kepatuhan material perpajakan, yakni sesuai isi dan jiwa Undang-undang perpajakan. Kepatuhan material dapat meliputi kepatuhan formal. Wajib Pajak yang memenuhi kepatuhan material adalah Wajib Pajak yang mengisi Surat Pemberitahuan dengan jujur, lengkap dan benar sesuai ketentuan dan melaporkan ke KPP sebelum batas waktu berakhir.

Seperti yang kita ketahui bahwa Pandemi Covid-19 muali menyebar di Indonesia pada Bulan Maret 2020 bertepatan dengan puncak pelaporan SPT Tahunan, Untuk itu Pemerintah Memberikan keringanan mengenai pelaporan SPT, Kementerian Keuangan 
melalui Direktorat Jenderal Pajak melakukan penghapusan sanksi administrasi atas keterlambatan pelaporan Surat Pemberitahuan (SPT) Tahunan tahun pajak 2019. Hal tersebut dilakukan sebagai salah satu kebijakan perpajakan sehubungan dengan penyebaran wabah virus corona (Covid-19).

Dalam Keputusan Direktur Jenderal Pajak Nomor Kep-156/PJ/2020 tentang Kebijakan Perpajakan Sehubungan dengan Penyebaran Wabah Virus Corona 2019 dikatakan, akibat penyebaran virus Covid-19 tersebut, pada 14 Maret 2020 sampai 30 April 2020 ditetapkan sebagai keadaan kahar.

Dikutip dari KOMPAS.COM bahwa DJP menyampaikan "Kepada Wajib Pajak orang pribadi yang melaporkan SPT Tahunan Tahun Pajak 2019 dan yang melakukan pembayaran atas jumlah pajak yang kurang dibayar dalam SPT Tahunan PPh orang pribadi Tahun Pajak 2019 sampai dengan tanggal 30 April 2020 diberikan penghapusan sanksi administrasi atas keterlambatan".

\section{TUJUAN}

Tujuan penelitian ini yaitu Untuk Mengetahui Mengenai Tingkat Kepatuhan Wajib Pajak (WP) dalam Melaporkan SPT Tahunananya di saat Sebelum dan Sesudah Pandemi Covid-19.

\section{TELAAH LITERATUR DAN PENGEMBANGAN HIPOTESIS}

\section{Gambaran Umum tentang Pajak}

\section{Definisi Pajak}

Pajak adalah kontribusi wajib kepada negara yang terutang oleh orang pribadi atau badan yang bersifat memaksa berdasarkan Undang-Undang, dengan tidak mendapatkan imbalan secara langsung dan digunakan untuk keperluan negara bagi sebesar-besarnya kemakmuran rakyat, pengertian pajak menurut para ahli:

1. Rochmat Soemitro

Pengertian pajak adalah iuran rakyat kepada Kas Negara berdasarkan undangundang (yang dapat dipaksakan) dengan tiada mendapat jasa timbal (kontra prestasi) yang langsung dapat ditunjukkan dan yang digunakan untuk membayar pengeluaran umum. Definisi tersebut kemudian dikoreksinya yang berbunyi sebagai berikut: Pajak adalah peralihan kekayaan dari pihak rakyat kepada Kas Negara untuk membiayai pengeluaran rutin dan surplusnya digunakan untuk public saving yang merupakan sumber utama untuk membiayai public investment.

2. Rifhi Siddiq

Pengertian Pajak adalah iuran yang dipaksakn pemerintahan suatu negara dalam periode tertentu kepada wajib pajak yang bersifat wajib dan harus dibayarkan oleh wajib pajak kepada negara dan bentuk balas jasanya tidak langsung.

3. Sommerfeld, Anderson, dan Brock Horace R

Pengertian Pajak adalah suatu pengalihan sumber dari sektor swasta ke sektor pemerintah, bukan akibat pelanggaran hukum, namun wajib dilaksanakan, berdasarkan ketentuan yang ditetapkan lebih dahulu, tanpa mendapat imbalan yang 
langsung dan proporsional, agar pemerintah dapat melaksanakan tugas-tugasnya untuk menjalankan pemerintahan.

4. Pengertian Pajak Menurut P. J. A. Adriani

Pengertian Pajak adalah iuran masyarakat kepada negara (yang dapat dipaksakan) yang terutang oleh yang wajib membayarnya menurut peraturanperaturan umum (undang-undang) dengan tidak mendapat prestasi kembali yang langsung dapat ditunjuk dan yang gunanya adalah untuk membiayai pengeluaranpengeluaran umum berhubung tugas negara untuk menyelenggarakan pemerintahan.

Jadi setelah pengertian pajak yang dikemukakakn oleh beberapa ahli dan dari UU KUP sendiri kita dapat menyimpulkan bahwa ada 5 unsur pengertian pajak yaitu :

1. Iuran/pungutan dari rakyat kepada negara

2. Pajak dipungut berdasarkan undang-undang

3. Pajak dapat dipaksakan

4. Tanpa jasa timbal atau kontraprestasi

5. Digunakan untuk membiayai rumah tangga negara (pengeluaran umum pemerintah).

\section{Fungsi Pajak}

Pajak mempunyai peranan yang sangat penting dalam kehidupan bernegara, khususnya di dalam pelaksanaan pembangunan karena pajak merupakan sumber pendapatan negara untuk membiayai semua pengeluaran termasuk pengeluaran pembangunan. Silahkan disimak berbagai fungsi pajak pada uraian di bawah ini.

1. Fungsi Anggaran (Budgetair)

Sebagai sumber pendapatan negara, pajak berfungsi untuk membiayai pengeluaran-pengeluaran negara. Untuk menjalankan tugas-tugas rutin negara dan melaksanakan pembangunan, negara membutuhkan biaya. Biaya ini dapat diperoleh dari penerimaan pajak. Dewasa ini pajak digunakan untuk pembiayaan rutin seperti belanja pegawai, belanja barang, pemeliharaan, dan lain sebagainya. Untuk pembiayaan pembangunan, uang dikeluarkan dari tabungan pemerintah, yakni penerimaan dalam negeri dikurangi pengeluaran rutin. Tabungan pemerintah ini dari tahun ke tahun harus ditingkatkan sesuai kebutuhan pembiayaan pembangunan yang semakin meningkat dan ini terutama diharapkan dari sektor pajak.

2. Fungsi Mengatur (Regulerend)

Pemerintah bisa mengatur pertumbuhan ekonomi melalui kebijaksanaan pajak. Dengan fungsi mengatur, pajak bisa digunakan sebagai alat untuk mencapai tujuan. Contohnya dalam rangka menggiring penanaman modal, baik dalam negeri maupun luar negeri, diberikan berbagai macam fasilitas keringanan pajak. Dalam rangka melindungi produksi dalam negeri, pemerintah menetapkan bea masuk yang tinggi untuk produk luar negeri.

\section{Fungsi Stabilitas}

Dengan adanya pajak, pemerintah memiliki dana untuk menjalankan kebijakan yang berhubungan dengan stabilitas harga sehingga inflasi dapat dikendalikan, Hal 
ini bisa dilakukan antara lain dengan jalan mengatur peredaran uang di masyarakat, pemungutan pajak, penggunaan pajak yang efektif dan efisien.

4. Fungsi Redistribusi Pendapatan

Pajak yang sudah dipungut oleh negara akan digunakan untuk membiayai semua kepentingan umum, termasuk juga untuk membiayai pembangunan sehingga dapat membuka kesempatan kerja, yang pada akhirnya akan dapat meningkatkan pendapatan masyarakat.

\section{Jenis Jenis Pajak}

Jenis-jenis pajak di Indonesia dikelompokkan berdasarkan cara pemungutan, sifat dan lembaga pemungutnya.

1. Jenis-jenis pajak berdasarkan cara pemungutannya terdiri dari :

a. Pajak Langsung

Pajak Langsung adalah pajak yang bebannya ditanggung sendiri oleh wajib pajak dan tidak dapat dialihkan kepada orang lain.Dengan kata lain, proses pembayaran pajak harus dilakukan sendiri oleh wajib pajak bersangkutan.Seorang anak, misalnya, tidak boleh mengalihkan pajak kepada orang tuanya. Begitupun seorang suami tidak boleh mengalihkan kewajiban pajaknya pada istri.

b. Pajak Tidak Langsung.

Pajak Tidak Langsung adalah pajak yang bebannya dapat dialihkan kepada pihak lain karena jenis pajak ini tidak memiliki surat ketetapan pajak. Artinya, pengenaan pajak tidak dilakukan secara berkala melainkan dikaitkan dengan tindakan perbuatan atas kejadian sehingga pembayaran pajak dapat diwakilkan kepada pihak lain

2. Jenis-jenis pajak berdasarkan sifatnya terdiri dari :

a. Pajak Subjektif

Pajak subjektif adalah pajak yang berpangkal pada subjeknya sedangkan pajak objektif berpangkal kepada objeknya. Suatu pungutan disebut pajak subjektif karena memperhatikan keadaan diri wajib pajak.Contoh pajak subjektif adalah pajak penghasilan (PPh) yang memperhatikan tentang kemampuan wajib pajak dalam menghasilkan pendapatan atau uang.

b. Pajak Objektif.

Pajak Onjektif merupakan pungutan yang memperhatikan nilai dari objek pajak. Contoh pajak objektif adalah Pajak Pertambahan Nilai (PPN) dari barang yang dikenakan pajak.

3. Jenis-jenis pajak berdasarkan lembaga pemungutannya terdiri dari Pajak pusat dan pajak daerah yang merupakan jenis pajak yang pengelompokannya berdasar pada lembaga pemungutannya.

a. Pajak Pusat

Pajak pusat adalah pajak yang dipungut dan dikelola oleh Pemerintah Pusat, dalam hal ini sebagian besar dikelola oleh Direktorat Jenderal Pajak (DJP).Hasil dari pungutan jenis pajak ini kemudian digunakan untuk membiayai belanja negara seperti pembangunan jalan, pembangunan sekolah, bantuan kesehatan 
dan lain sebagainya.Proses administrasi yang berkaitan dengan pajak pusat dilaksanakan di Kantor Pelayanan Pajak (KPP) atau Kantor Pelayanan Penyuluhan dan Konsultasi Perpajakan (KP2KP) dan Kantor Wilayah Direktorat Jenderal Pajak serta Kantor Pusat Direktorat Jenderal Pajak.Berikut ini pajak yang dikelola oleh pemerintah pusat:

1) Pajak Penghasilan (PPh)

2) Pajak Pertambahan Nilai (PPN)

3) Pajak Penjualan atas Barang Mewah (PPnBM)

4) Bea Materai

5) Pajak Bumi dan Bangunan (PBB perkebunan, Perhutanan, Pertambangan).

b. Pajak Daerah.

Pajak daerah merupakan pajak-pajak yang dipungut dan dikelola oleh Pemerintah Daerah baik di tingkat provinsi maupun kabupaten/kota. Hasil dari pungutan jenis pajak ini kemudian digunakan untuk membiayai belanja pemerintah daerah.Proses administasinya dilaksanakan di Kantor Dinas Pendapatan Daerah atau Kantor Pajak Daerah atau kantor sejenis yang dibawahi oleh pemerintah daerah setempat.Berikut ini pajak yang dikelola oleh pemerintah daerah:

1) Pajak provinsi terdiri dari:

a) Pajak Kendaraan Bermotor.

b) Bea Balik Nama Kendaraan Bermotor.

c) Pajak Bahan Bakar Kendaraan Bermotor.

d) Pajak Air Permukaan.

2) Pajak kabupaten/kota terdiri dari:

a) Pajak Hotel.

b) Pajak Restoran.

c) Pajak Hiburan.

d) Pajak Reklame.

e) Pajak Penerangan Jalan.

f) Pajak Mineral Bukan Logam dan Bantuan.

g) Pajak Parkir.

h) Pajak Air Tanah.

i) Pajak Sarang Burung Walet.

j) Pajak Bumi dan Bangunan Perdesaan dan Perkotaan.

k) Bea Perolehan Hak Atas Tanah dan/atau Bangunan.(Sekadar informasi saja, mulai tahun 2014, Pajak Bumi dan Bangunan (PBB) Perdesaan dan Perkotaan masuk dalam kategori pajak daerah. Sedangkan Pajak Bumi dan Bangunan (PBB) Perkebunan, Perhutanan dan Pertambangan masih tetap merupakan pajak pusat.

I) Pajak Rokok.

\section{Tata Cara Pemungutan Pajak}

Stelsel Pajak

Pemungutan pajak dapat dilakukan berdasarkan 3 stelsel, yaitu :

1. Stelsel Nyata 
Pengenaan Pajak didasarkan pada suatu objek (penghasilan yang nyata), pemungutan dilakukan pada akhir tahun pajak setelah penghasilan sesungguhnya diketahui. Pajak lebih realistis tapi baru dapat dikenakan di akhir periode.

2. Stelsel Anggapan (Fictieve Stelsel)

Pengenaan pajak didasarkan pada sebuah anggapan yang diatur Undang-Undang. Tanpa menunggu akhir tahun dan tidak berdasarkan keadaan sesungguhnya.

3. Stelsel Campuran

Merupakan salah satu kombinasi antara stelsel Nyata dan stelsel anggapan. Pada awal tahun dihitung berdasarkan anggapan dan akhir tahun disesuaikan dengan keadaan yang sebebnarnya.

\section{Sistem Pemungutan Pajak}

System pemunguatan pajak memilki 3 jenis yaitu :

\section{OfficialAssesstment System}

Adalah suatu sistem pemungutan yang memberi wewenang kepada pemerintah (fiskus) untuk menentukan besarnya pajak yang terutang oleh Wajib Pajak.

Ciri-cirinya:

a. Wewenang untuk menentukan besarnya pajak terutang ada pada fiskus

b. Wajib pajak bersifat pasif

c. Untang pajak timbul setelah dikeluarkan surat ketetapan pajak oleh fiskus.

2. Self Assesstment System

Adalah sistem pemungutan pajak yang memberi wewenang kepada Wajib Pajak untuk menentukan sendiri besarnya pajak yang terutang.

Ciri-cirinya :

a. Wewenang untuk menentukan besarnya pajak terutang ada pada Wajib Pajak sendiri.

b. Wajib Pajak aktif, mulai dari menghitung, menyetor dan melaporkan sendiri pajak yang terutang.

c. Fiskus tidak ikut campur dan hanya mengawasi.

\section{With Holding System}

Adalah suatu sistem pemungutan pajak yang memberi wewenang kepada pihak ketiga (bukan fiskus dan bukan Wajib Pajak yang bersangkutan) untuk menentukan besarnya pajak yang terutang oelh Wajib Pajak.

Ciri-cirinya : wewenang menentukan besarnya pajak yang terutang ada pada pihak ketiga, pihak selain fiskus dan Wajib Pajak. 


\section{Hak dan Kewajiban Wajib Pajak \\ Kewajiban Wajib Pajak}

Kewajiban Wajib Pajak menurut undang-undang nomor 28 tahun 2007 adalah sebagai berikut :

1. Mendaftarkan diri pada kantor Direktorat Jendral Pajak yang wilayah kerjanya meliputi tempat tinggal atau tempat kedudukan Wajib Pajak dan kepadanya diberikan Nomor Pokok Wajib Pajak, apabila telah memenuhi persyaratan subjektif dan objektif.

2. Melaporkan usahanya pada kantor Direktorat Jendral Pajak yang wilayah kerjanya tempat tinggal atau tempat kedudukan pengusaha dan tempat kegiatan usaha dilakukan untuk dikukuhkan menjadi pengusaha kena pajak.

3. Mengisi surat pemberitahuan dengan benar, lengkap, dan jelas, dalam bahasa Indonesia dengan menggunakan huruf latin, angka arab, satuan mata uang rupiah, serta menandatangani dan menyampaikan ke kantor Direktorat Jendral Pajak tempat Wajib Pajak terdaftar atau dikukuhkan atau tempat lain yang ditetapkan oleh Direktorat Jendral Pajak.

4. Menyampaikan surat pemberitahuan dalam bahasa Indonesia dengan menggunakan satuan mata uang asing selain rupiah yang diizinkan, yang pelaksanaannya diatur dengan atau berdasarkan Peraturan Menteri Keuangan.

5. Membayar atau menyetor pajak yang terutang dengan menggunakan surat setoran pajak ke kas Negara melalui tempat pembayaran yang diatur dengan atau berdasarkan Peraturan Menteri Keuangan.

6. Membayar pajak yang terutang sesuai dengan ketentuan perundang-undangan perpajakan, dengan tidak menggantungkan pada adanya surat ketetapan pajak.

7. Menyelenggarakan pembukuan bagi Wajib Pajak orang pribadi yang melakukan kegiatan usaha atau pekerjaan bebas atau Wajib Pajak badan, dan melakukan pencatatan bagi Wajib Pajak orang pribadi yang melakukan kegiatan usaha atau pelerjaan bebas.

8. Memperlihatkan dan/atau meminjamkan buku atau catatan, dokumen yang menjadi dasarnya, dan dokumen lain yang berhubungan dengan penghasilan yang diperoleh, kegiatan usaha, pekerjaan bebas Wajib Pajak, atau objek pajak yang terutang pajak.

\section{Hak Wajib Pajak}

Hak-hak Wajib Pajak menurut undang-undang No. 28 tahun 2007 adalah sebagai berikut :

1. Melaporkan beberapa masa pajak dalam 1 (satu) surat pemberitahuan masa.

2. Mengajukan surat keberatan dan banding bagi Wajib Pajak dengan kriteria tertentu.

3. Memperpanjang jangka waktu penyampaian surat pemberitahuan tahunan pajak penghasilan untuk paling lama 2 (dua) bulan dengan cara menyampaikan pemberitahuan secara tertulis atau dengan cara lain kepada Direktur Jendral Pajak.

4. Membetulkan surat pemberitahuan yang telah di sampaikan dengan menyampaikan pernyataan tertulis, dengan syarat Direktur Jendral Pajak belum melakukan tindakan pemeriksaan. 
5. Mengajukan permohonan pengembalian kelebihan pembayaran pajak.

6. Mengajukan keberatan kepada Direktur Jendral Pajak atas suatu :

a. Surat ketetapan pajak kurang bayar

b. Surat ketetapan pajak kurang bayar tambahan

c. Surat ketetapan pajak nihil

d. Surat ketetapan pajak lebih bayar

e. Pemotongan atau pemungutan pajak oleh orang pihak ketiga berdasarkan ketentuan peraturan perundang-undangan perpajakan.

7. Mengajukan permohonan banding kepada badan peradilan pajak atas surat keputusa keberatan.

8. Mengajukan keberatan kepada Direktorat Jendral Pajak atas suatu :

a. Surat ketetapan pajak kurang bayar

b. Surat ketetapan pajak kurang bayar tambahan

c. Surat ketetapan pajak nihil

d. Surat ketetapan pajak lebih bayar

e. Pemotongan atau pemungutan pajak oleh orang pihak ketiga berdasarkan ketentuan peraturan perundang-undangan perpajakan.

9. Mengajukan permohonan banding kepada badan peradilan pajak atau surat keputusan keberatan.

10. Menunjuk seorang kuasa dengan surat kuasa khusus untuk menjlankan hak dan memenuhi kewajiban sesuatu dengan ketentuan peraturan perundang-undangan perpajakan.

11. Memperoleh pengurangan atau penghapusan sanksi administrasi berupa bunga atas keterlambatan pelunasan kekurangan pembayaran pajak dalam hal Wajib Pajak menyampaikan pembetulan surat pemberitahuan tahunan pajak penghasilan sebelum tahun 2007, yang mengakibatkan pajak yang masih harus dibayar ,emjadi lebih besar dan dilakukan paling lama dalam jangka waktu 1 (satu) tahun setelah berlakunya UU No. 28 Tahun 2007.

\section{Surat Setoran Pajak (SSP) \\ Pengertian SSP}

SSP adalah bukti pembayaran atau penyetoran pajak yang telah dilakukan dengan menggunakan formulir atau telah dilakukan dengan cara lain ke kas negara melalui tempat pembayaran yang ditunjuk oleh Menteri Keuangan.

Bentuk formulir SSP ini sesuai dengan Peraturan Direktur Jenderal Pajak Nomor Per38/PJ/2009 Tentang Bentuk Formulir Surat Setoran Pajak sebagaimana telah diubah dengan Peraturan Dirjen Pajak Nomor PER-24/PJ/2013 tentang Perubahan Kedua Atas Peraturan Direktur Jenderal Pajak Nomor Per-38/PJ/2009 Tentang Bentuk Formulir Surat Setoran Pajak.

Setiap SSP hanya bisa digunakan untuk melakukan pembayaran atau penyetoran untuk satu jenis pajak, satu masa atau tahun pajak, satu Surat Ketetapan Pajak (SKP), Surat Tagihan Pajak (STP), Surat Ketetapan PBB, Surat Tagihan PBB, atau satu surat keputusan atas upaya hukum yang mengakibatkan jumlah pajak yang harus dibayar bertambah. 
Setiap penyampaian SSP harus menggunakan satu kode akun pajak dan satu jenis setoran pajak. Adapun, dalam aturan terbaru DJP mengubah dafatar kode akun dan kode jenis pajak sebagaimana terlampir dalam beleid tersebut. Perubahan ini dilakukan agar kode akun maupun kode jenis pajak sesuai dengan perkembangan aturan di bidang perpajakan.

Dalam aturan terbaru DJP juga mengakomodir tata cara pengisian SSP melalui aplikasi billing yang dimiliki DJP maupun sistem penerbitan kode billing lainnya yang terintegrasi dengan sistem billing DJP. Adapun dalam ketentuan yang lama, mekanisme penyampaian SSP melalui billing sistem tidak diatur.

\section{Fungsi Surat Setoran Pajak}

Fungsi utama SSP adalah sebagai bukti utama dan sarana administradi bagi Wajib pajak yang sudah melakukan pembayaran pajak sesuai aturan yang berlaku.Bagi wajib pajak yang telah menyelesaikan kewajibannya terkait dengan pajak, akan mendapat bukti pembayaran pajak yang telah disahkan atau telah mendapat validasi dari pejabat kantor atau pihak lainnya yang memiliki kewenangan dalam hal ini.

\section{Pembayaran Pajak}

Pembayaran pajak dapat dilakukan di bank-bank pemerintah maupun swasta dan kantor pos dengan menggunakan Surat Setoran Pajak (SSP) yang dapat diambil di KPP atau KP4 terdekat, atau dengan cara lain melalui pembayaran pajak secara elektronik (e-payment).

\section{Batas Waktu Pembayaran dan Penyetoran Pajak Masa}

Tabel 2.1 Batas Waktu Pembayaran dan Penyetoran Pajak Masa

\begin{tabular}{l|l|l}
\hline No & \multicolumn{1}{|c}{ Jenis SPT } & \multicolumn{1}{|c}{\begin{tabular}{c}
\multicolumn{1}{|c}{ Bembayas Waktu } \\
PASA
\end{tabular}} \\
\hline 1 & PPh Pasal 21/26 & Tgl. 10 bulan berikut \\
\hline 2 & PPh Pasal 23/26 & Tgl. 10 bulan berikut \\
\hline 3 & PPh Pasal 25 & Tgl. 15 bulan berikut \\
\hline 4 & $\begin{array}{l}\text { PPh Pasal 22, PPN \& PPn BM oleh } \\
\text { Bea Cukai }\end{array}$ & 1 hari setelah dipungut \\
\hline 5 & $\begin{array}{l}\text { PPh Pasal 22 - Bendaharawan } \\
\text { Pemerintah }\end{array}$ & $\begin{array}{l}\text { Pada hari yang sama saat penyerahan } \\
\text { barang }\end{array}$ \\
\hline 6 & PPh Pasal 22 - Pertamina & Sebelum Delivery Order dibayar \\
\hline 7 & PPh Pasal 22 - Pemungut tertentu & Tgl. 10 bulan berikut \\
\hline 8 & PPh Pasal 4 ayat (2) & Tgl. 10 bulan berikut \\
\hline 9 & PPN dan PPn BM - PKP & Tgl. 15 bulan berikut \\
\hline 10 & PPN dan PPn BM - Bendaharawan & Tgl. 17 bulan berikut \\
\hline 11 & $\begin{array}{l}\text { PPN \& PPn BM - Pemungut Non } \\
\text { Bendaharawan }\end{array}$ & Tgl. 15 bulan berikut \\
\hline
\end{tabular}

Batas Waktu Pembayaran dan Penyetoran Pajak Tahunan

Tabel 2.2 Batas Waktu Pembayaran dan Penyetoran Pajak Tahunan

\begin{tabular}{l|c|c}
\hline No & Jenis SPT & $\begin{array}{c}\text { Batas Waktu } \\
\text { Pembayaran/Penyetoran }\end{array}$ \\
\hline
\end{tabular}




\begin{tabular}{l|l|l}
\hline 1 & PPh - Badan, OP, PPh Pasal 21 & $\begin{array}{l}\text { Tgl. 25 bulan ketiga setelah berakhirnya } \\
\text { tahun atau bagian tahun pajak }\end{array}$ \\
\hline 2 & PBB & $\begin{array}{l}6 \text { (enam) bulan sejak tanggal diterimanya } \\
\text { SPPT }\end{array}$ \\
\hline 3 & BPHTB & $\begin{array}{l}\text { Dilunasi pada saat terjadinya perolehan } \\
\text { hak atas tanah dan bangunan }\end{array}$ \\
\hline
\end{tabular}

\section{Surat Pemberitahuan (SPT)}

\section{Pengertian Surat Pemberitahuan (SPT)}

Surat Pemberitahuan (SPT) adalah laporan pajak yang disampaikan kepada pemerintah Indonesia melalui Direktorat Jenderal Pajak. Ketentuan mengenai SPT diatur dalam Undang-Undang Nomor 28 Tahun 2007 tentang Ketentuan Umum dan Tata Cara Perpajakan.

\section{Fungsi Surat Pemberitahuan (SPT)}

Dalam undang-undang tersebut ditegaskan, pemerintah mengharuskan seluruh wajib pajak untuk melaporkan SPT sesuai dengan ketentuan yang berlaku,jadi fungsi dari SPT adalah:

1. Melaporkan pelunasan atau pembayaran pajak yang sudah dilakukan, baik secara personal maupun melalui pemotongan penghasilan dari perusahaan dalam jangka waktu satu tahun.

2. Melaporkan harta benda yang dimiliki di luar penghasilan tetap dari pekerjaan utama.

3. Melaporkan penghasilan lainnya yang termasuk ke dalam kategori objek pajak maupun bukan objek pajak.

\section{Jenis Surat Pemberitahuan (SPT)}

1. SPT Tahunan

SPT Tahunan merupakan laporan pajak yang disampaikan satu tahun sekali (tahunan) baik oleh wajib pajak badan maupun wajib pajak pribadi, yang berhubungan dengan perhitungan dan pembayaran pajak penghasilan, objek pajak penghasilan, dan/atau bukan objek pajak penghasilan, dan/atau harta dan kewajiban sesuai dengan peraturan pajak untuk satu tahun pajak, atau bagian dari tahun pajak.

2. SPT Masa

Di Indonesia terdapat 10 jenis SPT Masa. SPT Masa tersebut dinamakan berdasarkan nomor pasal, di mana aturan pajak tersebut diatur, 10 jenis SPT Masa tersebut adalah:
a. PPh Pasal 21/26.
b. PPh Pasal 22.
c. PPh Pasal 23/26.
d. PPh Pasal 25.
e. PPh Pasa 4 ayat (2).
f. PPh Pasal 15.
g. PPN (Pajak Pertambahan Nilai). 
h. PPN bagi Pemungut .

i. $\quad$ PPN bagi Pengusaha Kena Pajak Pedagang Eceran yang menggunakan nilai lain sebagai Dasar Pengenaan Pajak.

j. Pajak Penjualan atas Barang Mewah.

\section{Jenis Formulir dalam Pelaporan SPT}

Setiap pekerja/pegawai pasti menerima bukti potong sebagai bukti setoran pajak yang telah dipungut dan dilaporkan oleh perusahaan pemberi kerja. Formulir bukti potong tersebut terbagi menjadi dua yakni :

1. Formulir $1721 \mathrm{~A} 1$ khusus untuk para karyawan yang bekerja di perusahaan milik swasta.

2. Formulir 1721 A2 untuk karyawan yang menjabat sebagai Pegawai Negeri Sipil.

Kedua formulir ini nantinya akan menjadi pedoman wajib pajak ketika lapor pajak.Selain formulir bukti potong, kita juga mengenal tiga jenis formulir SPT PPh Orang Pribadi, yaitu :

1. Formulir 1770 yang ditujukan bagi wajib pajak yang bekerja tanpa ikatan kerja tertentu,

2. Formulir $1770 \mathrm{SS}$ yang ditujukan untuk perseorangan atau pribadi dengan jumlah penghasilan kurang dari atau sama dengan Rp60 juta setahun dan hanya bekerja pada satu perusahaan,

3. Formulir $1770 \mathrm{~S}$ untuk wajib pajak pribadi dengan penghasilan tahunan lebih dari Rp60 juta dan bekerja pada dua perusahaan atau lebih.

\section{Batas Waktu Pelaporan SPT}

Tabel 2.3 Batas Waktu Pelaporan SPT

\begin{tabular}{l|l|l}
\hline No & \multicolumn{1}{|c}{ Jenis SPT } & \multicolumn{1}{c}{ Batas Waktu Pelaporan } \\
\hline 1 & \multicolumn{1}{|c}{ MASA } \\
\hline 2 & PPh Pasal 23/26 & Tgl. 20 bulan berikut \\
\hline 3 & PPh Pasal 25 & Tgl. 20 bulan berikut \\
\hline 4 & $\begin{array}{l}\text { PPh Pasal 22, PPN \& PPn BM oleh Bea } \\
\text { Cukai }\end{array}$ & 7 hari setelah pembayaran \\
\hline 5 & $\begin{array}{l}\text { PPh Pasal 22 - Bendaharawan } \\
\text { Pemerintah }\end{array}$ & Tgl. 14 bulan berikujt \\
\hline 6 & PPh Pasal 22 - Pertamina & \\
\hline 7 & PPh Pasal 22 - Pemungut tertentu & Tgl. 20 bulan berikut \\
\hline 8 & PPh Pasal 4 ayat (2) & Tgl. 20 bulan berikut \\
\hline 9 & PPN dan PPn BM - PKP & Tgl. 20 bulan berikut \\
\hline 10 & PPN dan PPn BM - Bendaharawan & Tgl. 14 bulan berikut \\
\hline 11 & $\begin{array}{l}\text { PPN \& PPn BM - Pemungut Non } \\
\text { Bendaharawan }\end{array}$ & Tgl. 20 bulan berikut \\
\hline & \multicolumn{2}{|c|}{ TAHUNAN } \\
\hline
\end{tabular}




\begin{tabular}{l|l|l}
\hline No & \multicolumn{1}{|c|}{ Jenis SPT } & \multicolumn{2}{|c}{ Batas Waktu Pelaporan } \\
\hline 1 & PPh - Badan, OP, PPh Pasal 21 & $\begin{array}{l}\text { Tgl. 31 bulan ketiga setelah } \\
\text { berakhirnya tahun atau bagian tahun } \\
\text { pajak }\end{array}$ \\
\hline 2 & PBB & --- \\
\hline 3 & BPHTB & ---- \\
\hline
\end{tabular}

\section{Sanksi Tidak atau Terlambat Melaporkan SPT}

SPT dilaporkan menggunakan formulir tertentu, tergantung dari jenis pajak yang akan dilaporkan. Untuk setiap jenis laporan memiliki tanggal jatuh tempo yang berbeda untuk waktu pembayaran dan pelaporan. Jika SPT tidak dilaporkan pada waktunya, maka dikenakan sanksi sebesar:

1. Rp $100.000,00$ untuk SPT Tahunan bagi wajib pajak pribadi.

2. Rp $1.000 .000,00$ untuk SPT Tahunan bagi Pengusaha Kena Pajak.

3. Rp 500.000,00 untuk SPT Masa PPN

4. Rp $100.000,00$ untuk SPT Masa lainnya.

Sama seperti melaporkan pajak, membayar pajak juga merupakan kewajiban warga negara. Jika Wajib Pajak tidak membayar pajak tepat waktu, maka terdapat sanksi pajak yang tidak ringan.

\section{Kepatuhan Wajib Pajak \\ Pengertian Wajib Pajak}

Wajib Pajak adalah orang pribadi atau badan yang ditentukan untuk melakukan kewajiban perpajakan yaitu memungut atau memotong pajak tertentu yang sesuai dengan ketentuan peraturan perundang-undangan perpajakan. (www.djponline.pajak.go.id)

Dapat disimpulkan bahwa Wajib Pajak adalah subyek pajak yang terdiri dari orang pribadi atau badan yang memenuhi syarat-syarat obyektif yang ditentukan oleh UndangUndang, yaitu menerima atau memperoleh penghasilan kena pajak yang mempunyai hak dan kewajiban perpajakan sesuai dengan ketentuan peraturan perundang - undangan. Subyek pajak adalah orang atau badan yang bertempat tinggal atau berkedudukan di Indonesia. Obyek pajak adalah setiap tambahan kemampuan ekonomis yang diperoleh Wajib Pajak yang digunakan untuk konsumsi atau untuk menambah kekayaan Wajib Pajak tersebut. Penghasilan Kena Pajak adalah penghasilan yang melebihi penghasilan tidak kena pajak bagi Wajib Pajak dalam negeri. Kewajiban pajak merupakan kewajiban publik yang bersifat pribadi, yang tidak dapat dialihkan kepada orang lain. Wajib Pajak dapat menunjuk atau meminta bantuan atau memberi kuasa pada orang lain, akan tetapi kewajiban publik yang melekat pada dirinya, khususnya mengenai pajak-pajak langsung tetap ada padanya. Dia tetap bertanggung jawab walaupun orang lain dapat ikut di pertanggung jawabkan.

\section{Pengertian Kepatuhan Wajib Pajak}

kepatuhan perpajakan dapat didefinisikan sebagai suatu keadaan dimana wajib pajak memenuhi semua kewajiban perpajakan dan melaksanakan hak perpajakan. 
Kewajiban dan hak dibagi ke dalam dua kepatuhan meliputi kepatuhan formal dan kepatuhan material. Kepatuhan formal yang dimaksud misalnya ketentuan batas waktu penyampaian SPT Tahunan tanggal 31 maret. Apabila wajib pajak telah melaporkan SPT tahunan sebelum atau pada tanggal 31 maret, maka wajib pajak telah memenuhi kepatuhan formal, namun isinya belum tentu memenuhi ketentuan material, yaitu suatu keadaan dimana wajib pajak secara subtantive memenuhi semua ketentuan material perpajakan, yakni sesuai isi dan jiwa Undang-undang perpajakan. kepatuhan perpajakan dapat didefinisikan sebagai keadaan dimana Wajib Pajak memenuhi semua kewajiban perpajakan dan melaksanakan hak perpajakannya.

Direktorat Jenderal Pajak telah mengeluarkan criteria Wajib Pajak Patuh. Wajib Pajak Patuh adalah Wajib Pajak yang ditetapkan oleh Direktorat Jenderal Pajak yang memenuhi criteria tertentu yang dapat diberikan pengembalian pendahuluan atas kelebihan pembayaran pajak. Kriteria Wajib Pajak Patuh tersebut antara lain:

1. Tepat waktu dalam menyampaikan surat pemberitahuan untuk semua jenis pajak dalam dua tahun terakhir.

2. Tidak mempunyai tunggakan pajak untuk semua jenis pajak, kecuali telah memperoleh ijin untuk mengangsur atau menunda pembayaran.

3. Tidak pernah dijatuhi hukuman karena melakukan tindak pidana di bidang perpajakan dalam jangka waktu 10 (sepuluh) tahun terakhir.

4. Wajib pajak yang laporan keuangannya untuk 2 (dua) tahun terakhir di audit oleh akuntan public dengan pendapat wajar tanpa pengecualian tanpa merugikan laba fiskal .

\section{Upaya Peningkatan Kepatuhan Wajib Pajak}

Terdapat tiga strategi dalam meningkatkan kepatuhan Wajib Pajak melalui administrasi perpajakan, yaitu:

1. Membuat program dan kegiatan yang dapat menyadarkan dan meningkatkankepatuhan secara sukarela.

2. Meningkatkan pelayanan terhadap Wajib Pajak yang sudah patuh supayadapat mempertahankan atau meningkatkan kepatuhannya.

3. Dengan menggunakan program atau kegiatan yang dapat memerangi ketidakpatuhan sehingga akan mendorong wajib pajak meningkatkan kepatuhan membayar pajak

\section{Tingkat kepatuhan wajib pajak}

Untuk mengetahui prosentase (\%) tingkat kepatuhan Wajib Pajak dengan rumus :

\section{Tingkat kepatuhan $=$ Jumlah SPT terlapor $\times 100 \%$ Wp terdaftar}

Klasifikasi rasio perhitungan kepatuhan penyampaian SPT Tahunan Pajak adalah sebagai berikut :

Tabel 2.4 Norma Absolut Skala Lima

\begin{tabular}{l|l}
\hline Tingkat Penguasaan & Skor \\
\hline
\end{tabular}




\begin{tabular}{c|c}
\hline & Standar \\
\hline $90-100 \%$ & Sangat Tinggi \\
\hline $80-89 \%$ & Tinggi \\
\hline $65-79 \%$ & Cukup \\
\hline $55-64 \%$ & Kurang \\
\hline $0-54 \%$ & Rendah \\
\hline
\end{tabular}

Sumber: Wayan Nurkancana dan Sunartana (1983: 80).

\section{HASIL PENELITIAN DAN PEBAHASAN}

\section{Pengertian Wajib pajak dan Pengelompokannya Pengertian Wajib Pajak}

Menurut Direktorat Jenderal Perpajakan, Wajib Pajak adalah orang pribadi atau badan, meliputi pembayar pajak, pemotong pajak, dan pemungut pajak, yang mempunyai hak dan kewajiban perpajakan sesuai dengan ketentuan peraturan perundang-undangan perpajakan.

\section{Pengelompokan Wajib Pajak}

Secara Umum Wajib Pajak Dikelompokam menjadi dua, Yaitu Wajib Pajak Orang Pribadi dan Wajib Pajak Badan, Berikut penjelasannya :

a) Wajib Pajak Orang Pribadi

Wajib Pajak Orang Pribadi adalalah Orang Pribadi Yang telah menerima dan/atau memperoleh Penghasilan Yang bersumber Dari Indonesia atau Melalui Badan Usaha Tetap (BUT) Di Indonesia

b) Wajib Pajak Badan

Wajib Pajak Badan adalah sekumpulan orang atau kelompok yang bergabung dan bekerjasama dalam bentuk modal yang diwajibkan untuk terlibat dalam ketentuan perpajakan terlepas dari mereka melakukan usaha atau tidak melakukan usaha. Wajib Pajak Badan meliputi:

1. Perseroan Terbatas (PT)

2. Perseroan Komanditer (CV)

3. Perseroan Lainnya

4. Badan Usaha Milik Negara atau Badan Usaha Milik Daerah

5. Firma

6. Koperasi

7. Kongsi

8. Persekutuan

9. Perkumpulan

10. Organisasi

11. Lembaga

12. Bentuk Badan Lain

13. Bentuk Usaha Tetap

\section{Tingkat Kepatuhan Wajib Pajak}


Untuk mengukur tingkat kepatuhan Wajib Pajakdalam pelaporan SPT maka digunakan rasio sebagai berikut:

Tingkat kepatuhan $=$ Jumlah WP yang Melaporkan SPT $\times 100 \%$

\section{Jumlah Wp terdaftar}

Selanjutnya Untuk mengidentifikasi tingkat kepatuhan Wajib Pajak digunakan dengan pedoman Norma Absolut Skala Lima Sebagai Berikut :

Tabel 4.4 Norma Absolut Skala Lima

\begin{tabular}{c|c}
\hline $\begin{array}{c}\text { Tingkat } \\
\text { Penguasaan }\end{array}$ & $\begin{array}{c}\text { Skor } \\
\text { Standar }\end{array}$ \\
\hline $90-100 \%$ & Sangat Tinggi \\
\hline $80-89 \%$ & Tinggi \\
\hline $65-79 \%$ & Cukup \\
\hline $55-64 \%$ & Kurang \\
\hline $0-54 \%$ & Rendah \\
\hline
\end{tabular}

Sumber: Wayan Nurkancana dan Sunartana (1983: 80).

\section{Penerimaan Pajak Di KPP Pratama Mataram Barat}

Berikut adalah Bukti Penerimaan Pajak di KPP Pratama Mataran Barat Untuk Tahun Pajak 2017-2019.

Tabel 4.5 Penerimaan Pajak di KPP Pratama Mataram Barat Tahun 2018-

2020.

\begin{tabular}{c|c|c|l|l}
\hline $\begin{array}{c}\text { Tahun } \\
\text { Pajak }\end{array}$ & Target & Realisasi & Persentase & $\begin{array}{c}\text { Kriteria } \\
\text { kepatuahan }\end{array}$ \\
\hline 2018 & $1.178 .975 .896 .001,00$ & $1.111 .686 .250 .985,00$ & $94,30 \%$ & Sangat tinggi \\
\hline 2019 & $1.238 .403 .152 .000,00$ & $1.148 .954 .271 .985,00$ & $92,78 \%$ & Sangat tinggi \\
\hline 2020 & $1.324 .589 .728 .000,00$ & $1.081 .667 .741 .976,00$ & $81,67 \%$ & Tinggi \\
\hline
\end{tabular}

Sumber : Seksi PDI KPP Pratama Mataram Barat 2021

Dilihat dari Tabel 4.5 Persentasi tingkat kepatuhan Wajib Pajak di KPP Pratama mataram Barat dalam Membayarkan pajakanya di Tahun 2018 adalah sebesar 94,30 \% yang tergolong dalam kriteria kepatuhan yang sangat tinggi, kemudian menurun di tahun 2019 menjadi 92,78 \% namun masih termasuk dalam kriteria kepatuhan sangat tinggi, dan selanjutnya di tahun 2020 juga kembali menurun menjadi $81,67 \%$ yang mana kriteria kepatuhannya tergolong Tinggi.

Dari Uraian di atas dapat Disimpulkan Bahwa persentase Tingkat Kepatuhan Wajib Pajak Dalam Membayarkan Pajaknya di KPP Pratama Mataram Barat di Tahun 20182020 tergolong tinggi menurut Norma Absolut Skala Lima.

\section{Tingkat Kepatuhan Wajib Pajak Orang Pribadi}

Berikut adalah Tabel Jumlah Wajb Pajak Orang Pribadi Terdaftar dan melaporkan SPT tepat waktu di KPP Pratama Mataram Barat Tahun 2018-2020 :

Tabel 4.6 Wajib Pajak Orang Pribadi Terdaftar dan Wajib Pajak Orang Pribadi yang Melaporkan SPT Tahunan Tepat Waktu Tahun 


\begin{tabular}{c|c|c|c} 
No. & Tahun & $\begin{array}{c}\text { Jumlah WP } \\
\text { OP Terdaftar }\end{array}$ & $\begin{array}{c}\text { Jumlah WP OP Lapor SPT } \\
\text { Tahunan }\end{array}$ \\
\hline 1 & 2018 & 95.220 & 35.560 \\
\hline 2 & 2019 & 99.966 & 28.019 \\
\hline 3 & 2020 & 131.312 & 32.174 \\
\hline \multicolumn{4}{l}{ Sumber : Seksi PDI KPP Pratama Mataram Barat (2021). }
\end{tabular}

Adapun proses Perhitungan Persentasi Tingkat Kepatuhan Wajib Pajak Orang Pribadi dalam Pelaporan SPT Tahunan tahun 2018-2020 adalah Sebagai berikut :

1. Tingkat Kepatuhan Wajib Pajak Orang Pribadi Dalam Pelaporan SPT Tahun pajak 2018 :

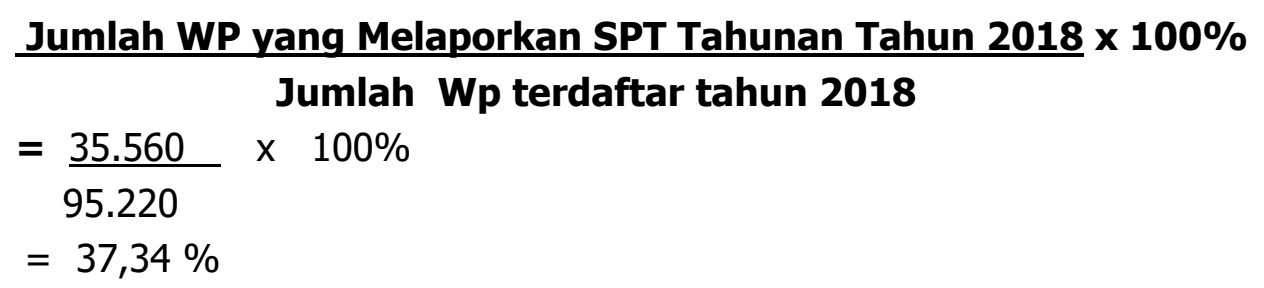

2. Tingkat Kepatuhan Wajib Pajak Orang Pribadi Dalam Pelaporan SPT Tahun pajak 2018 :

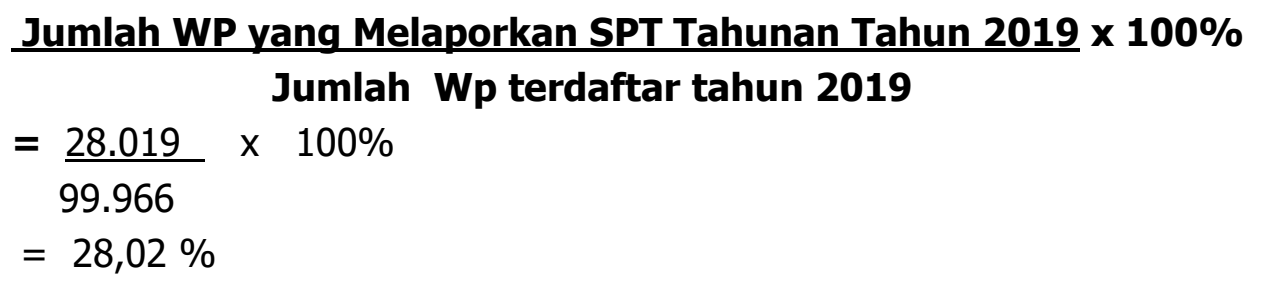

3. Tingkat Kepatuhan Wajib Pajak Orang Pribadi Dalam Pelaporan SPT Tahun pajak 2020 :

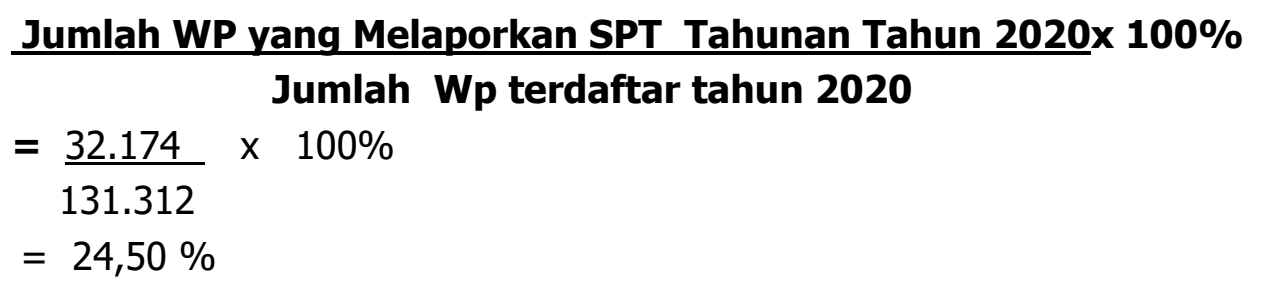

Dari Uraian Perhitungan Persentasi Tingkat Kepatuhan Wajib Pajak di atas, maka Terbentukah Tabel Tingkat Kepatuahan Wajib Pajak Orang Pribadi Dalam Pelaporan SPT Tahunan Tahun 2018-2019 sebagai berikut :

Tabel 4. 7 Tingkat Kepatuhan Wajib Pajak Orang Pribadi dalamPelaporan SPT Tahunan Tahun 2018-2020

\begin{tabular}{c|c|c|c|c|c}
\hline No. & $\begin{array}{c}\text { Tahun } \\
\text { Pajak }\end{array}$ & $\begin{array}{c}\text { JumlahWP OP } \\
\text { Terdaftar }\end{array}$ & $\begin{array}{c}\text { JumlahWP OP } \\
\text { Lapor SPT } \\
\text { Tahunan }\end{array}$ & Persentase & Kriteria \\
\hline
\end{tabular}




\begin{tabular}{l|l|r|r|r|r}
\hline 1 & 2018 & 95.220 & 35.560 & $37,34 \%$ & Rendah \\
\hline 2 & 2019 & 99.966 & 28.019 & $28,02 \%$ & Rendah \\
\hline 3 & 2020 & 131.312 & 32.174 & $24,50 \%$ & Rendah \\
\hline
\end{tabular}

Dilihat dari Tabel 4.7 Tingkat kepatuhan Wajib Pajak Orang Pribadi dalam pelaporan SPT Tahunan di KPP Pratama Mataram Barat pada saat Sebelum pandemi Covid-19 Di Tahun 2018 dan 2019 adalah sebesar 37,34\%, dan 28,02\% Kemudian Menurun Setelah Pandemi Covid-19 Di Tahun 2020 menjadi 24,50\%, yang tergolong dalam kategori rendah menurut norma skala lima.

Dari Uraian di atas dapat Disimpulkan Bahwa Tingkat Kepatuhan Wajib Pajak Orang Pribadi Dalam Melaporkan SPT Tahunan di KPP Pratama Mataram Barat sejak tahun 2018 dan 2019 mengalami penurunan dan masih tergolong Rendah Bahkan sebelum Pademi Covid-19, kemudian Terus Menurun setelah Pandemi Covid-19 di Tahun 2020.

\section{Tingkat Kepatuhan Wajib Pajak Badan}

Berikut adalah Tabel Jumlah Wajb Pajak Badan yang Terdaftar dan melaporkan SPT tepat waktu di KPP Pratama Mataram Barat Tahun 2018-2020 :

Tabel 4.8 Wajib Pajak Badan Terdaftar dan Wajib Pajak Badan yang Melaporkan SPT Tahunan Tepat Waktu Tahun 2018-2019

\begin{tabular}{c|c|c|c}
\hline No. & Tahun & $\begin{array}{c}\text { Jumlah WP } \\
\text { Badan Terdaftar }\end{array}$ & $\begin{array}{c}\text { Jumlah WP Badan Lapor } \\
\text { SPT Tahunan }\end{array}$ \\
\hline 1 & 2018 & 11.756 & 2.643 \\
\hline 2 & 2019 & 12.443 & 1.920 \\
\hline 3 & 2020 & 13.194 & 1.057 \\
\hline
\end{tabular}

Sumber : Seksi PDI KPP Pratama Mataram Barat (2021).

Adapun proses Perhitungan Persentasi Tingkat Kepatuhan Wajib Badan dalam Pelaporan SPT Tahunan Tahun 2018-2020 adalah Sebagai berikut :

1. Tingkat Kepatuhan Wajib Pajak Badan Dalam Pelaporan SPT Tahun 2018 :

Jumlah WP yang Melaporkan SPT Tahunan Tahun 2018 x 100\% Jumlah Wp terdaftar tahun 2018

$$
\begin{aligned}
& =\frac{2.643}{11.756} \times 100 \% \\
& =22,49 \%
\end{aligned}
$$

2. Tingkat Kepatuhan Wajib Pajak Badan Dalam Pelaporan SPT Tahun 2018 :

Jumlah WP yang Melaporkan SPT Tahunan Tahun $2019 \times 100 \%$ Jumlah Wp terdaftar tahun 2019

$$
=\underline{1.920} \times 100 \%
$$


12.443

$=15,43 \%$

3. Tingkat Kepatuhan Wajib Badan Dalam Pelaporan SPT Tahun 2020 :

Jumlah WP yang Melaporkan SPT Tahunan Tahun $2020 \times 100 \%$ Jumlah Wp terdaftar tahun 2020

$=\underline{1.057} \times 100 \%$

13.194

$=8,01$

Dari Uraian Perhitungan Persentasi Tingkat Kepatuhan Wajib Pajak di atas, maka Terbentukah Tabel Tingkat Kepatuahan Wajib Pajak Orang Pribadi Dalam Pelaporan SPT Tahunan Tahun 2018-2019 sebagai berikut :

Tabel 4.9 Tingkat Kepatuhan Wajib Pajak Badan dalamPelaporan SPT

Tahunan, Tahun 2018-2020

\begin{tabular}{c|l|r|c|c|c}
\hline No. & Tahun Pajak & $\begin{array}{c}\text { JumlahWP } \\
\text { Badan } \\
\text { Terdaftar }\end{array}$ & $\begin{array}{c}\text { JumlahWP Badan } \\
\text { Lapor SPT } \\
\text { Tahunan }\end{array}$ & Persentase & Kriteria \\
\hline 1 & 2018 & 11.756 & 2.643 & $22,49 \%$ & Rendah \\
\hline 2 & 2019 & 12.443 & 1.920 & $15,43 \%$ & Rendah \\
\hline 3 & 2020 & 13.194 & 1.057 & $8,01 \%$ & Rendah \\
\hline
\end{tabular}

Diliahat dari Tabel 4.9 Tingkat kepatuhan Wajib Pajak Badan dalam pelaporan SPT Tahunan di KPP Pratama Mataram Barat pada saat Sebelum Pandemi Covid-19 Di Tahun 2018 dan 2019 adalah sebesar 22,49\%, dan 15,43\%, Kemudian Menurun Setelah Pandemi Covid-19 Di Tahun 2020 menjadi 8,01\%, yang tergolong dalam kategori rendah menurut norma skala lima.

Dari Uraian di atas dapat Disimpulkan Bahwa Tingkat Kepatuhan Wajib Pajak Badan Dalam Melaporkan SPT Tahunan di KPP Pratama Mataram Barat sejak tahun 2018 dan 2019 mengalami penurunan dan masih tergolong rendah Bahkan sebelum Pademi Covid-19, Kemudian Terus Menurun setelah Pandemi Covid-19 di Tahun 2020.

\section{Perbandingan Antara Teori Dan Praktek}

Perbandingan antara teori dan praktek yang pernah penulis dapatkan dibangku kuliah dengan praktek langsung dilapangan akan ditulis dari berbagai aspek yang dapat dilihat ppada tabel / matrik berikut : 
Tabel 4.10 Perbandingan Antara Teori dan Praktek

\begin{tabular}{|c|c|c|c|c|}
\hline No & Uraian & Teori & Praktek & Kesesuaian \\
\hline 1 & $\begin{array}{l}\text { Surat Pemberi } \\
\text { tahuan (SPT) }\end{array}$ & $\begin{array}{l}\text { - Form SPT } 1770 \text { di gunakan untuk WP } \\
\text { OP yang yang memiliki status sebagai } \\
\text { usahawan, pekerja bebas, dan WP OP } \\
\text { yang bekerja lebih dari } \\
\text { satuInstansi/perusahan dengan PPh } \\
\text { Final. } \\
\text { - Form SPT } 1770 \text { SS digunakan Untuk WP } \\
\text { OP yang memiliki pengahasilan } \\
\text { pertahunnya kurang dari Rp. } \\
60.000 .000 \\
\text { - Form SPT } 1770 \text { S digunakan untuk WP } \\
\text { OP yang memiliki Penghasilan } \\
\text { pertahunnya lebih dari Rp.60.000.000 } \\
\text { - Form SPT } 1771 \text { digunakan untuk WP } \\
\text { Badan }\end{array}$ & Sama & Sesuai \\
\hline 2 & Pelaporaran & $\begin{array}{l}\text { - Batas Pelaporan untuk SPT Tahunan } \\
\text { WP OP yaitu pada } 31 \text { Maret dan Untuk } \\
\text { WP Badan pada } 30 \text { April } \\
\text { - Pelaporan SPT Tahunan secara Online } \\
\text { dapat di lakukan Melalui Efiling untuk } \\
\text { Form SPT 1770S dan SPT 1770SS, dan } \\
\text { melalui E-Form untuk Form SPT } 1770 \\
\text { dan SPT } 1771\end{array}$ & Sama & Sesuai \\
\hline 3 & Bukti potong & $\begin{array}{l}\text { - Bukti potong 1721-A1 digunakan untuk } \\
\text { WP OP yang berstatus sebagai } \\
\text { Pegawai/ pensiunana } \\
\text { - Bukti potong 1721-A2 digunakan WP } \\
\text { OP yang berstatsus sebagai PNS, } \\
\text { TNI/POLRI, atau pejabat Negara atau } \\
\text { pensiunana, dan Bukan Bukti potong } \\
\text { PPh pasal } 22\end{array}$ & $\begin{array}{l}\text { Untuk pelaporan SPT } \\
\text { Tahunana dengan } \\
\text { Form SPT 1770SS } \\
\text { bisa tidak } \\
\text { menyertakan bukti } \\
\text { potong, namun } \\
\text { Untuk pelaporan SPT } \\
\text { Tahunan dengan } \\
\text { Form } 1770 \mathrm{~S} \\
\text { diharuskan untuk } \\
\text { meyertakan bukti } \\
\text { potong }\end{array}$ & Sesuai \\
\hline
\end{tabular}

\section{SIMPULAN}

Kesimpulan yang dapat ditarik dari Bab Pembahasan pada penelitian ini adalah :

1. Mengetahui persentase tingkat Kepatuhan Wajib Pajak Orang Pribadi dan Badan dalam Melaporkan SPT Tahunan pada masa sebelum dan sesudah Pandemi Covid19 di KPP Pratama Mataram Barat yang terus mengalami Penurunan dari tahun 2018-2020 dan masih tergolong dalam Kategori Rendah yang mana Berbanding terbalik dengan persentasi tingkat penerimaan pajaknya yang tergolong tinggi. sehingga dapat disimpulkan bahawa faktor penyebab rendahnya tinggkat 
kepatuhan Wajib Pajak dalam melaporkan SPT Tahunannya adalah karena kurangnya kesadaran dari WP Tentang pentingnya melaporkan Pajaknya dan kurangnya pengetahuan dalam pelaporan SPT Tahunan secara Online melalui EFiling.

2. Setelah dilakukan Perbandingan antara Teori atau Peraturan Perundang-Undangan tentang metode Pelaporan, ketentuan SPT, dan perilhal Bukti potong yang dijadikan sebagai syarat dan ketentuan untuk pelaporan SPT tahunan tidak ditemukannya adanya perbedaan atau dengan kata lain sudah sesuai dengan Praktek.

\section{DAFTAR PUSTAKA}

Anonim, (2021, Maret 3) "Buku Pedoman Praktek Kerja Lapangan (PKL)", 2021 Akademik D3 Perpajakan Fakultas Ekonomi Dan Bisnis Universitas Mataram.

Anonim (2021, Maret 4) "Pengertian Pajak dari para ahli';dikutip dari:https://www.merdeka.com/jabar/pengertian-pajak-menurut-para-ahli-.

Anonim (2021, maret 5) "lima unsur pokok pajak" dikutip dari :https://dwiifatma.wordpress.com/2012/12/10/lima-unsur-pokok-pajak.

Anonim (2021, Maret 5) "fungsi pajak" dikutip dari:https://www.pajak.go.id.

Anonim (2021, Maret 5) "Sistem Pemungutan Pajaka di Indonesia" dikutip dari :https://klikpajak.id/blog/lapor-pajak/sistem-pemungutan-pajak-di-indonesia.

Kementrian Keuangan, (2021, Maret 4) "pengertian pajak"dikutip dari buku UU KUP dan peraturan pelaksanaannya oleh kemengkeu dan dirjen Pajak.

KP3SKP (2021, Maret 6) "Susunan Dalam Satu Naskah Undang-Undang Perpajakan" Buku dari KP3SKP (Panitia Penyelengaran Sertifikasi Konsultan Pajak Komite Pelaksana). 